\title{
PENERAPAN METODE STUDENT TEAMS ACHIEVEMENT DIVISION (STAD) DALAM MEDIA PEMBELAJARAN MULTIMEDIA KREATIF
}

\author{
Syarifah Eiva Fatdha'), Marlis Alamsyah') \\ ${ }^{1}$ Teknologi Informasi, STMIK Amik Riau \\ Jl Purwodadi Indah Km.10 Panam Pekanbary Riau \\ email: syarifaheiva@stmik-amik-riau.ac.id \\ ${ }^{2}$ Teknik Informatika, STMIK Amik Riau \\ Jl Purwodadi Indah Km.10 Panam Pekanbary Riau \\ email: marlisalamsyah@stmik-amik-riau.ac.id
}

\begin{abstract}
In today's technological developments, it is certain that every activity in human life has taken advantage of the role of technology, including in the world of education. However, there are still many schools that have not implemented technology as a means of supporting education, in general the existing learning models still convey material through traditional methods. So that it has a direct impact on students, namely by lack of student interest in learning, student activity is less and tends to be passive and learning outcomes are low. To improve this, the researchers applied creative multimedia learning media and used the Student Teams Achievement Division (STAD) method. This research was an action research using multimedia. Each meeting includes stages including planning, implementing actions, observing and reflecting. Through the application of a creative multimedia learning model using the Student Teams Achievement Division (STAD) method, it is hoped that it can improve teacher skills, student activities and learning outcomes for elementary school students in general and in learning. The application of the learning model can be used as a solution to improve the quality of learning in certain subjects.
\end{abstract}

Keywords: Student Teams Achievement Division (STAD), learning media, creative multimedia.

\begin{abstract}
Abstrak
Dalam perkembangan teknologi saat ini, dapat dipastikan setiap aktivitas dalam kehidupan manusia telah memanfaatkan peranan teknologi, termasuk dalam dunia pendidikan. Namun masih banyak sekolah yang belum menerapkan teknologi sebagai sarana penunjang pendidikan, pada umumnya model pembelajaran yang ada masih menyampaikan materi melalui metode tradisional. Sehingga berdampak langsung pada siswa yaitu dengan kurangnya minat siswa dalam pembelajaran, keaktifan siswa kurang dan cenderung pasif dan hasil belajar rendah. Untuk memperbaiki hal tersebut peneliti menerapkan media pembelajaran multimedia kreatif dan menggunakan metode Student Teams Achievement Division (STAD).Penelitian ini adalah penelitian tindakan menggunakan multimedia. Setiap pertemuan meliputi tahapan-tahapan antara lain perencanaan, pelaksaan tindakan,observasi dan refleksi. Melalui penerapan model pembelajaran multimedia kreatif dengan menggunakan metode Student Teams Achievement Division (STAD) diharapkan dapat meninggkatkan ketarampilan guru, aktivitas siswa dan hasil belajar untuk siswa Sekolah Dasar pada umumnyadan $\mathrm{g}$ di bpembelajaran. Penerapan model pembelajaran dapat dijadikan sebagai solusi untuk meningkatkan kualitas pembelajaran pada mata pelajaran tertentu.
\end{abstract}

Kata Kunci : Student Teams Achievement Division (STAD), media pembelajaran, multimedia kreatif 


\section{PENDAHULUAN}

Sekolah dasar merupakan jenjang pendidikan dasar yang berfugsi sebagai peletakan dasar-dasar keilmuan dan membantu pengoptimalan perkembangan anak serta menjembatani siswa untuk melanjutkan ke jenjang berikutnya. Fungsi tersebut dapat tercapai apabila dilaksanakan pembimbingan pembelajaran oleh guru dengan baik dan benar. Pembelajaran di sekolah dasar meliputi beberapa bidang studi yaitu matematika salah satu dari mata pelajaran yg merupakan bidang studi yang dipelajari. Secara umum, tujuan pembelajaran matematika di sekolah dasar adalah agar siswa mempunyai pemahaman dan keterampilan dalam berpikir logis, analitas, sistematis, kritis, dan kreatif. Salah satu faktor penyebab rendahnya pemahaman siswa pada mata pelajaran matematika adalah pembelajaran matematika yang berlangsung cenderung teacher centered dimana guru sebagai pusat pembelajaran. Guru melakukan pembelajaran secara konvensional (tradisional) dengan mentransfer pengetahuan yang dimiliki pada siswa dan siswa menerimanya secara pasif dan tidak kritis. Keadaan ini membuat siswa menggunakan rumus matematika tanpa memahami darimana dan bagaimana rumus tersebut terbentuk. Hal ini menyebabkan siswa menjadi pasif dan kurang termotivasi dalam mengikuti pembelajaran.

Berdasarkan hasil wawancara yang telah dilakukan didapatkan bahwa penggunaan media (alat peraga) dalam proses belajar masih menggunakan papan tulis dan tidak menggunakan teknologi. Upaya untuk menumbuhkan motivasi belajar siswa melalui penerapan metode pembelajaran yang tepat dan dengan penggunaan media yang menarik selama proses pembelajaran. Metode pembelajaran yang diperlukan untuk mengatasi hal tersebut haruslah bersifat menarik dan interaktif, penggunaan metode Student Teams Achievement Divisions (STAD) dapat menangani masalah tersebut. Metode Student Teams Achievement Divisions (STAD) adalah model pembelajaran kooperatif yang dapat memberikan prestasi belajar akademik siswa meningkat dan siswa dapat menerima berbagai keragaman dari sudut pandang temannya, serta pengembangan keterampilan sosial. Metode ini memiliki tahapan yang meliputi antara lain pembekalan materi, pembentukan grup, pengadaan kuis, proses penilaian dan pemberian penghargaan. Dengan menggunakan metode ini dapat mewujudkan tujuan diatas yang merupakan tolak ukur keberhasilan proses pembelajaran.

\section{TINJAUAN PUSTAKA}

\subsection{Metode Student Teams Achievement Divisions (STAD)}

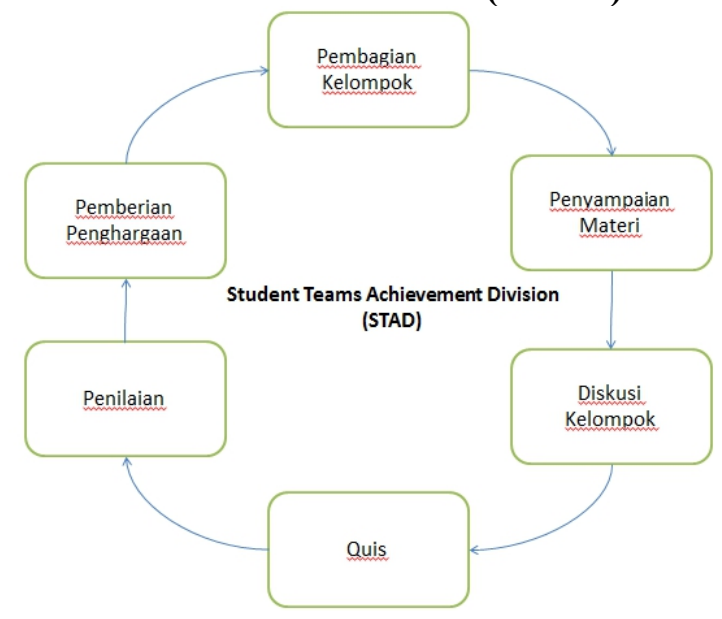

Gambar 1 Metode Student Teams Achievement Division 
Metode Student Teams Achievement Divisions (STAD) merupakan pendekatan cooperative learning yang menekankan pada akttvitas dan interaksi diantara siswa untuk saling memotivasi dan saling membantu dalam menguasai materi pelajaran guna meraih prestasi maksimal dalam pelajaran [1]. Jika siswa menginginkan kelompoknya memperoleh hadiah maka mereka harus membantu teman sekelompok dalam mempelajari pelajaran. Siswa diberi waktu untuk bekerja sama setelah pelajaran diberikan oleh guru, tetapi tidak saling membantu ketika menjalani kuis, sehingga setiap siswa harus menguasai materi yang diberikan.

\subsection{Langkah-Langkah STAD}

Langkah-langkah penerapan dalam model pembelajaran kooperatif tipe STAD yang diterapkan dalam penelitian ini ada enam langkah sebagai berikut, [1] :

a. Pembagian kelompok dengan cara membagi siswa menjadi beberapa kelompok yang setiap kelompoknya terdiri dari 4-5 siswa yang memprioritaskan heterogenitas (keragaman) kelas dalam prestasi akademik, gender/jenis kelamin, ras atau etnik.

b. Penyampaian materi dari guru yaitu proses pembelajaran dalam kegiatan presentasi, guru menggunakan media, demonstrasi, masalah nyata yang terjadi dalam kehidupan sehari-hari dan menyampaikan tugas ataupun pekerjaan yang harus dikerjakan disertai cara-cara untuk mengerjakannya.penyampaian materi,

c. Kegiatan belajar dalam tim (diskusi kelompok) akan terlaksana ketika siswa belajar dalam kelompok yang telah dibentuk dan guru menyiapkan lembar kerja sebagai pedoman untuk melaksanakan kerja kelompok sehingga semua anggota menguasai dan memberikan kontribusi hasil pemikiran untuk dipresentasikan. Selama kelompok bekerja, guru melakukan pengamatan, memberikan bimbingan, dorongan dan bantuan apabila diperlukan oleh siswa. Kerja tim dalam kelompok ini merupakan ciri terpenting dari STAD.

d. Pemberian kuis (Evaluasi) dilakukan oleh Guru dengan cara mengevaluasi hasil belajar melalui pemberian kuis tentang materi yang dipelajari dan melakukan penilaian terhadap presentasi yang dilaksanakan di akhir pertemuan dari hasil kerja masingmasing kelompok.

e. Penyimpulan skor terhadap kemampuan individual disetiap siswa dapat menyumbang poin maksimum kepada timnya dalam sistem penskoran, namun tidak seorang siswa pun dapat melakukan seperti itu tanpa menunjukkan perbaikan atas kinerja masa lalu. Setiap siswa diberikan sebuah skor dasar, yang dihitung dari kinerja rata-rata siswa pada kuis serupa sebelumnya. Kemudian siswa memperoleh poin untuk timnya didasarkan pada berapa banyak skor kuis mereka melampaui skor dasar mereka.

f. Pemberian pengakuan kelompok Setelah masing-masing memperoleh predikat, guru memberikan penghargaan kepada masing-masing kelompok sesuai predikatnya. Pengakuan dari guru merupakan salah satu cara untuk memberikan motivasi kepada siswa untuk melakukan kompetisi yang positif. Penghargaan tidak harus berupa materi. Penghargaan juga dapat diberikan dalam bentuk nilai tambahan atau hal non materi lain.

\subsection{Kelebihan STAD}

Berdasarkan karakteristiknya ialah setiap siswa memiliki kesempatan untuk memberikan kontribusi yang substansial kepada kelompoknya, dan posisi anggota kelompok adalah setara, menggalakkan interaksi secara aktif dan positif dan kerjasama anggota kelompok menjadi lebih baik, membantu siswa untuk memperoleh hubungan 
pertemanan lintas rasial yang lebih banyak, siswa memiliki dua bentuk tanggung jawab belajar[1].

\subsection{Kekurangan STAD}

Kelemahan STAD adalah pembelajaran menggunakan model ini membutuhkan waktu yang relatif lama, dengan memperhatikan tiga langkah STAD yang menguras waktu seperti penyajian materi dari guru, kerja kelompok dan tes individual/kuis, karena rata-rata jumlah siswa di dalam kelas adalah 20-30 orang, maka guru kurang maksimal dalam mengamati belajar kelompok secara bergantian. dituntut bekerja cepat dalam menyelesaikan tugastugas yang berkaitan dengan pembelajaran yang telah dilakukan, antara lain koreksi pekerjaan siswa, menentukan perubahan kelompok belajar, memerlukan waktu dan iaya yang banyak untuk mempersiapkan dan kemudian melaksanakan pembelajaran kooperatif tersebut, membutuhkan waktu yang lebih lama untuk peserta didik sehingga sulit mencapai target kurikulum.

\subsection{Media Pembelajaran}

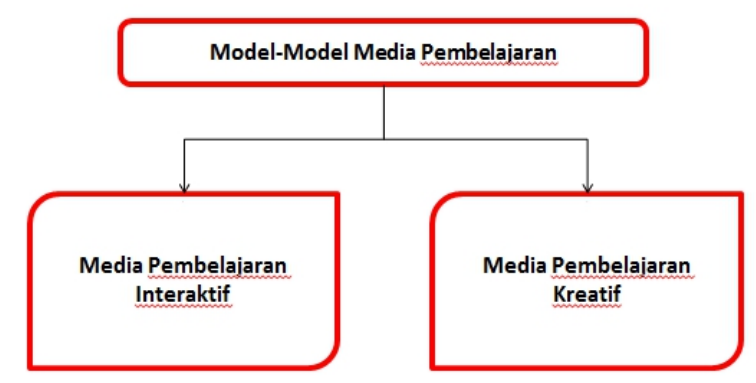

Gambar 2. Model-Model Media Pembelajaran

Media pembelajaran adalah alat bantu dalam proses pembelajaran yang berfungsi untuk merangsang interaksi dan kreativitas siswa dalam proses pembelajaran. Penggunaan media pengajaran dapat membantu pencapaian keberhasilan belajar. Dari pengertian di atas dapat disimpulkan bahwa media pembelajaran adalah alat bantudalam proses belajar mengajaruntuk merangsang pikiran, perasaan, perhatian dan kemampuan atau ketrampilan pembelajar sehingga dapat mendorong terjadinya proses belajar[7].

\subsubsection{Media Pembelajaran Interaktif}

Media pembelajaran interaktif merupakan suatu aplikasi pembelajaran yang ditujukan untuk menyalurkan materi-materi berupa pengetahuan, keterampilan dan sikap agar dapat merangsang pikiran, perasaan, perhatian dan kemauan siswa dalam belajar sehingga secara sengaja proses belajar terjadi, bertujuan dan terkendali[4].

\subsubsection{Media Pembelajaran Kreatif}

Pembelajaran kreatif adalah pembelajaran menekankan kepada guru ataupun tutor dalam menangani dan memfasilitasi kegiatan belajar, sehingga belajar menjadi kondusif dan nyaman menuntut pendidik mengemas bahan pembelajaran sehingga siswa dapat terangsang untuk melakukan kegiatan-kegiatan kreatif [4].

\subsection{Matematika}

Matematika merupakan abstraksi dari dunia nyata, menggunakan bahasa symbol, dan menganut pola pikir deduktif. Matematika pada umumnya terdapat didalam pikiran ataupun 
Hal : $284-297$

ide, oleh sebab itu objek matematika bersifat abstrak. Abstraksi sendiri dapat diartikan sebagai upaya untuk menciptakan definisi dengan jalan memusatkan perhatian pada sifat yang umum dari berbagai objek dan mengabaikan sifat-sifat yang berlainan[5].

\subsection{Unified Modeling Language (UML)}

Unified Modeling Language (UML) merupakan metodologi dalam mengembangkan sistem berorientasi objek dan juga merupakan alat untuk mendukung pengembangan system [2]. UML didefinisikan sebagai bahasa visual untuk menjelaskan, memberikan spesifikasi, merancang, membuat model, dan mendokumentasikan aspek aspek dari sebuah system.

\subsection{Penelitian Terdahulu}

Berdasarkan penelitian dalan jurnal yang berjudul "Penerapan Model Pembelajaran Kooperatif Tipe Stad Untuk Meningkatkan Aktivitas Dan Hasil Belajar Siswa Kelas X-1 Sma Negeri 1 Tanjungpura Pada Pelajaran Kimia", menyimpulkan bahwa: Penggunaan model pembelajaran kooperatif tipe STAD yang digunakan dalam pembela- jaran kimia dapat meningkatkan aktivitas belajar siswa.[6]

Berdasarkan penelitian dalan jurnal yang berjudul "Peningkatan Kerjasama Pada Materi Perubahan Benda Menggunakan Model Pembelajaran Cooperativetipe Stad" menyimpulkan bahwa : Pembelajaran kooperatif tipe STAD pada perubahan benda disekitar kita dapat meningkatkan hasil belajar dan kerjasama siswa. Model pembelajaran kooperatif STAD dapat meningkatkan kerjasama siswa hingga 74\%.[7]

Berdasarkan penelitian dalan jurnal yang berjudul "Penerapan Model Pembelajaran Kooperatif Tipe Stad Untuk Meningkatkan Hasil Belajar Pkn Siswa Kelas Iv Sd Negeri 79 Pekanbaru", menyimpulkan bahwa Bagi siswa agar bekerja sama dalam kelompok dan membantu temannnya yang belum mengerti. Hal ini perlu dilakukan supaya siswa tidak bekerja secara individu serta ingin cepat menyelesaikan sendiri masalah yang ada pada LKPD.[10]

Berdasarkan penelitian dalan jurnal yang berjudul "Pengembangan Multimedia Interaktif Dalam Pembelajaran Matematika" menyimpulkan bahwa : Multimedia interaktif matematika yang dikembangkan ini akan lebih layak apabila telah disosialisasikan dan dibuktikan secara eksperimen kepada siswa dalam kegiatan pembelajaran, sehingga diperoleh data berupa nilai kemampuan siswa pada kegiatan pembelajaran.[8]

\section{METODE PENELITIAN}

\subsection{Analisa Perangkat Lunak}

Analisa perangkat lunak merupakan tahapan awal yang harus dilakukan sebelum membangun sebuah sistem. Tahapan ini terdiri dari analisa masalah dan analisa kebutuhan sistem.

\subsection{Masalah}

Secara umum, tujuan pembelajaran matematika di sekolah dasar adalah agar siswa mempunyai pemahaman dan keterampilan dalam berpikir logis, analitas, sistematis, kritis, dan kreatif. Salah satu faktor penyebab rendahnya pemahaman siswa pada mata pelajaran matematika adalah pembelajaran matematika yang berlangsung cenderung teacher centered dimana guru sebagai pusat pembelajaran. 
Guru melakukan pembelajaran secara konvensional (tradisional) dengan mentransfer pengetahuan yang dimiliki pada siswa dan siswa menerimanya secara pasif dan tidak kritis. Keadaan ini membuat siswa menggunakan rumus matematika tanpa memahami darimana dan bagaimana rumus tersebut terbentuk. Hal ini menyebabkan siswa menjadi pasif dan kurang termotivasi dalam mengikuti pembelajaran.

\subsection{Analisa Kebutuhan Sistem}

Analisa kebutuhan sistem dilakukan untuk mengetahui kebutuhan perangkat lunak yang digunakan sebagai alat dalam membangun sistem, adapun perangkat lunak yang digunakan dalam penelitian ini sebagai berikut :

1. Sistem operasi Windows 1064 bit sebagai system operasi untuk membangun system pada PC.

2. Aplikasi Adobe Flash yang digunakan untuk membangun media pembelajaran kreatif.

3. Adobe Photoshop sebagai aplikasi pembuatan animasi atau gambar yang akan dimasukkan kedalam sistem.

\subsubsection{Gambaran Sistem yang Diusulkan Menggunakan Metode STAD}

Gambaran yang diusulkan pada sistem yang telah diterapkan langsung kedalam metode STAD. Pembuatan dan diskusi kelompok merupakan tahapan pertama yang dilakukan oleh guru untuk menerapkan metode STAD, setelah itu guru akan mempresentasikan materi pembelajaran, materi pembelajaran merupakan sistem yang ingin dibangun sehingga nantinya mengahasilkan media pembelajaran kreatif. Setelah dilakukannya presentasi materi pembelajaran, siswa akan diberikan beberapa soal quis untuk mengetahui pemahaman siswa terhadap materi yang telah dipresentasikan. Pada tahapan quis ini penilaian dilakukan secara individual tidak lagi kelompok, dimana bertujuan untuk mengetahui pemahaman materi terhadapa masing-masing siswa. Setelah tahapan quis selesai guru akan langsung memeriksa hasil quis dengan melakukan pembagian tugas dimasing-masing kelompok, siswa akan langsung mengetahui nilai yang diperoleh pada quis yang telah dilakukan. Siswa yang memiliki nilai terbaik akan diberikan penghargaan oleh guru, dimana penghargaan ini bertujuan untuk memotivasi siswa agar dapat saling berkompetisi dengan baik.

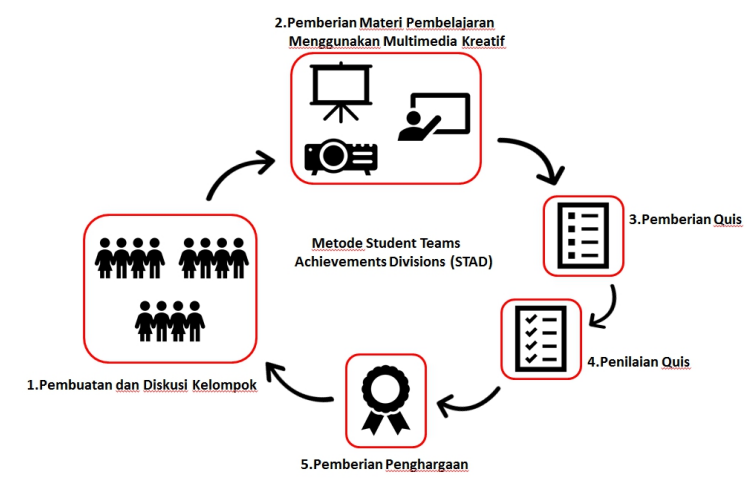

Gambar 3.Gambaran Sistem dengan Metode STAD 


\section{HASIL DAN PEMBAHASAN}

\subsection{Rancangan Sistem Usulan}

Rancangan sistem usulan ini dibuat dengan menggunakan model diagram yaitu Unified Modelling Language (UML) perancangan sistem usulan ini diperlukan untuk memberikan gambaran langkah demi langkah dalam pembuatan media pembelajaran yang telah penulis rancang. Adapun rancangan sistem usulan adalah sebagai berikut :

\section{Usecase Diagram}

Use case merupakan suatu prilaku sistem sebagai respon dari suatu aksi atau permintaan dari luar sistem. Berikut ini adalah pemodelan use case diagram pada sistem yang dibangun:

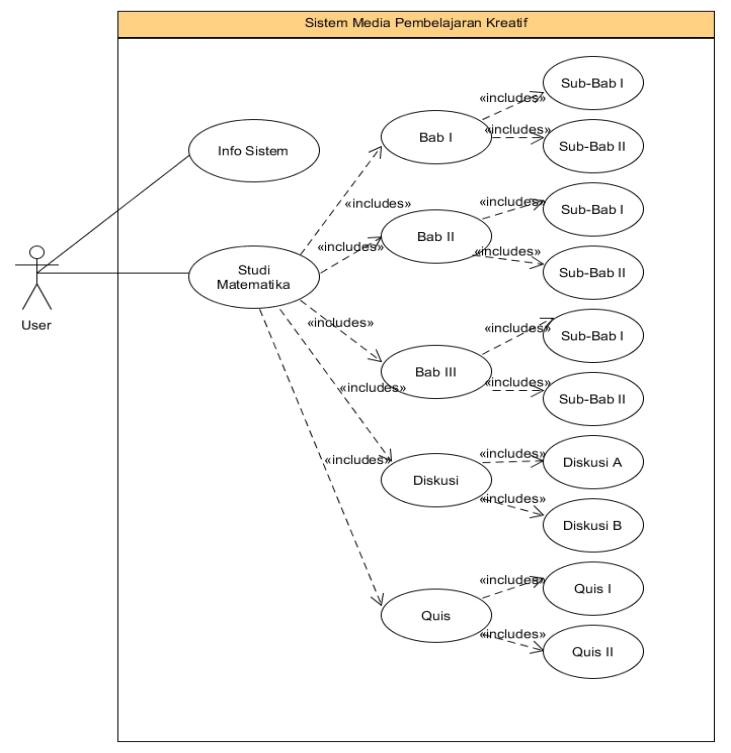

Gambar 4 Use Case Diagram Sistem

Dari gambar diatas dapat dilihat bahwa sistem yang dirancang adalah sebagai berikut : Pengguna sistem yang merupakan guru-guru dapat mengakses sistem, didalam sistem pengguna dapat melihat info aplikasi yang berisikan informasi pengembang sistem media pembelajaran kreatif. Pengguna juga dapat memilih studi yang telah tersedia pada sistem, pada halaman studi terdapat beberapa pilihan materi-materi pembelajaran dari bab pertama hingga bab ketiga dan juga terdapat informasi referensi atau sumber buku yang digunakan sesuai dengan kurikulum sekolah. Pada Halaman materi yang berisikan subbab-subbab yang terdapat pada materi bab yang telah dipilih, disetiap subbab tersebut juga terdapat quis atau latihan yang dapat dikerjakan oleh siswa nantinya.

\section{Activity Diagram}

Activity diagram menggambarkan bagaimana aktivitas yang terjadi pada sistem yang akan dirancang. Activity diagram pada sistem yang akan penulis bangun adalah sebagai berikut:

\subsection{Activity Diagram Memilih Studi Pada Media Pembelajaran Kreatif}

Activity ini menggambarkan aktifitas pengguna dalam memilih studi pada sistem media pembelajaran kreatif. Adapun gambaran activity diagramnya sebagai berikut : 
Hal : $284-297$

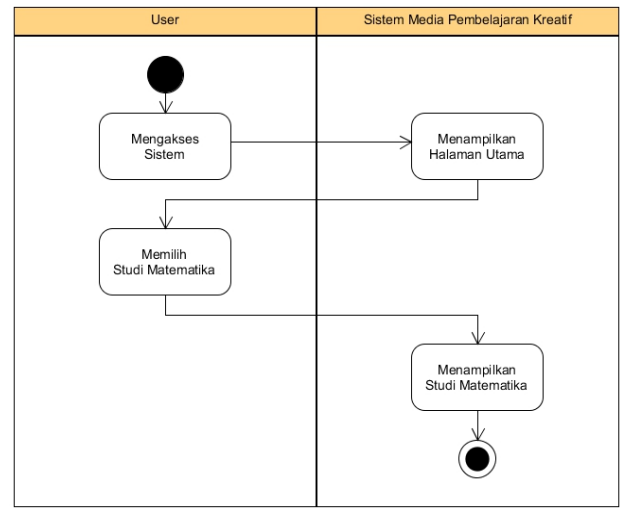

Gambar 5. Activity Diagram Memilih Studi Pada Media Pembelajaran Kreatif

\subsection{Activity Diagram Memilih Materi Pada Media Pembelajaran Kreatif}

Activity ini menggambarkan aktifitas pengguna dalam memilih materi pada bab yang ada pada studi matematika. Berikut gambaran activity diagramnya :

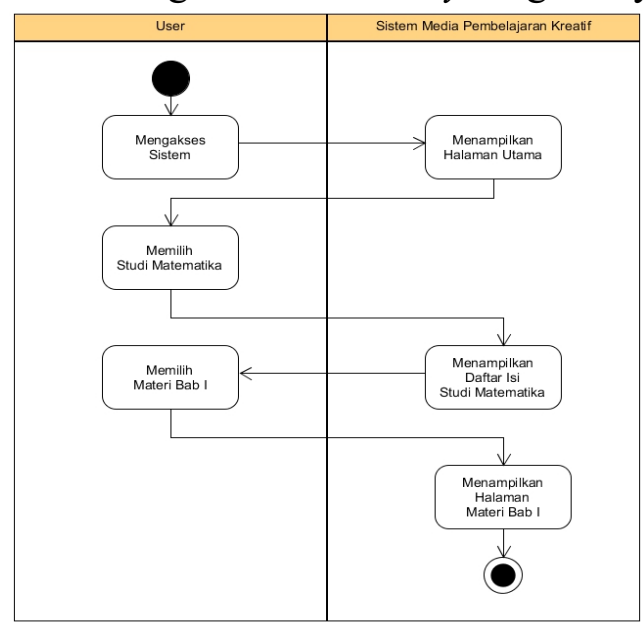

Gambar 6.Activity Diagram Memilih Materi Pada Media Pembelajaran Kreatif

b. Activity Diagram Info Sistem Media Pembelajaran Kreatif

Activity ini menggambarkan aktifitas pengguna dalam mengakses informasi pengembang dari sistem media pembelajaran kreatif. Gambaran activity diagramnya sebagai berikut : 


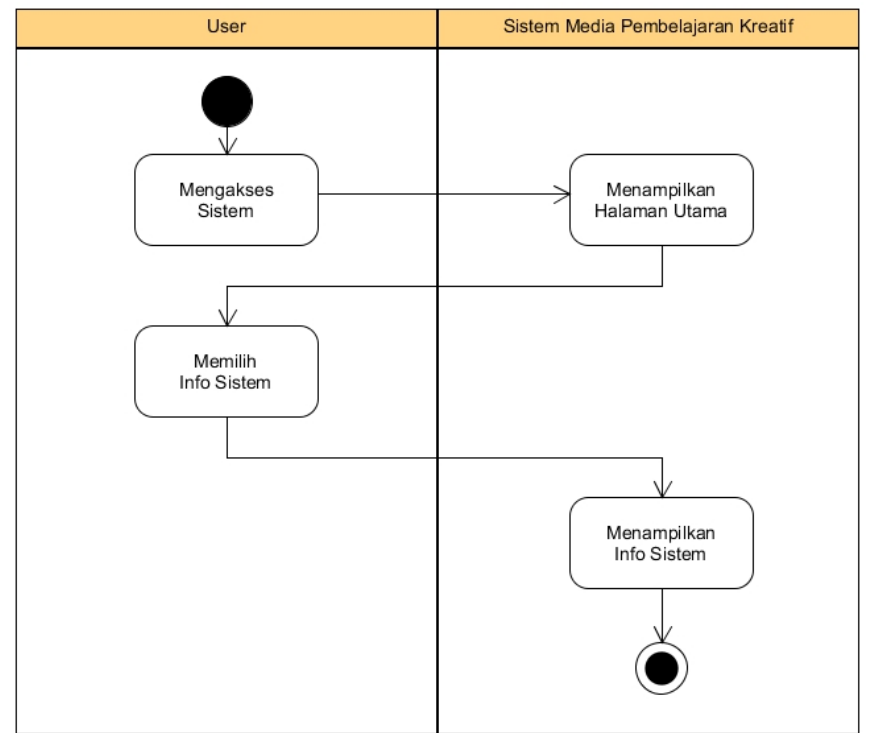

Gambar 7. Activity Diagram Info Media Pembelajaran Kreatif

\section{Sequence Diagram}

Sequence diagram merupakan diagram yang menggambarkan rangkaian langkahlangkah yang dilakukan sebagai respon dari sebuah event untuk menghasilkan output tertentu.

1. Sequence Diagram Akses Sistem Media Pembelajaran Kreatif

Sequence diagram mengakses sistem media pembelajaran kreatif dimana terdapat alur untuk mengakses semua fungsi yang ada pada sistem. Pengguna dapat memilih halaman studi yang diinginkan dengan menenekan tombol studi matematika, sistem akan memanggil halaman studi kemudian akan ditampilkan kepengguna. Didalam halaman studi pengguna dapat mengakses beberapa fungsi yaitu halaman materi dan halaman quis.

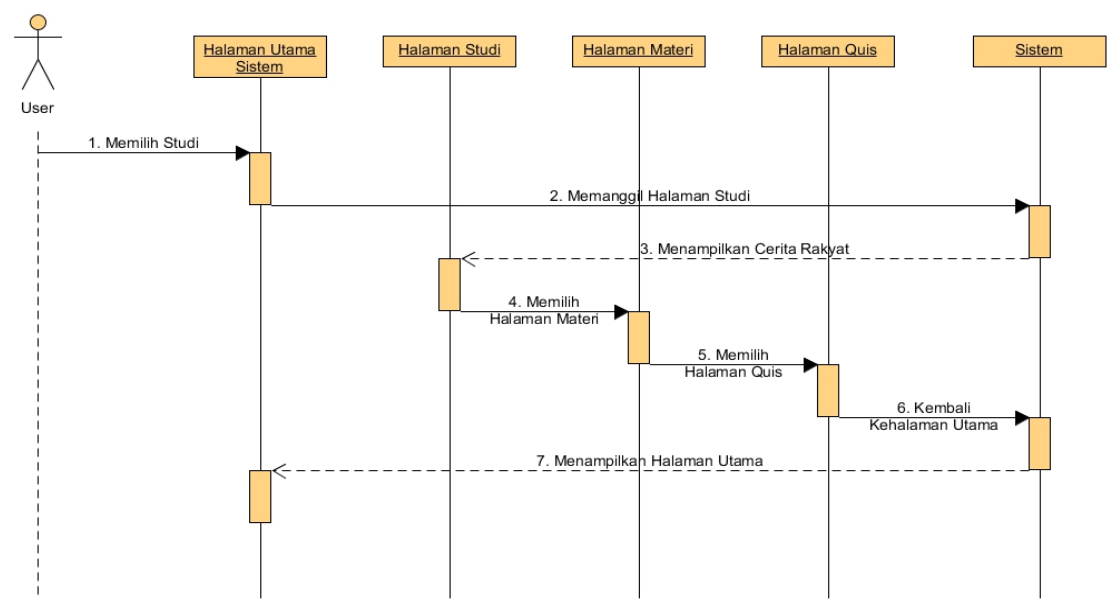

Gambar 8. Sequence Diagram Akses Sistem Media Pembelajaran Kreatif

2. Sequence Diagram Info Sistem Media Pembelajaran Kreatif

Sequence diagram info sistem merupakan sebuah alur dimana pengguna yang ingin mengkases halaman info sistem media pembelajaran kreatif. Halaman info sistem ini berupa halaman yang menampilkan informasi pengembang dari sistem media pembelajaran kreatif ini. 


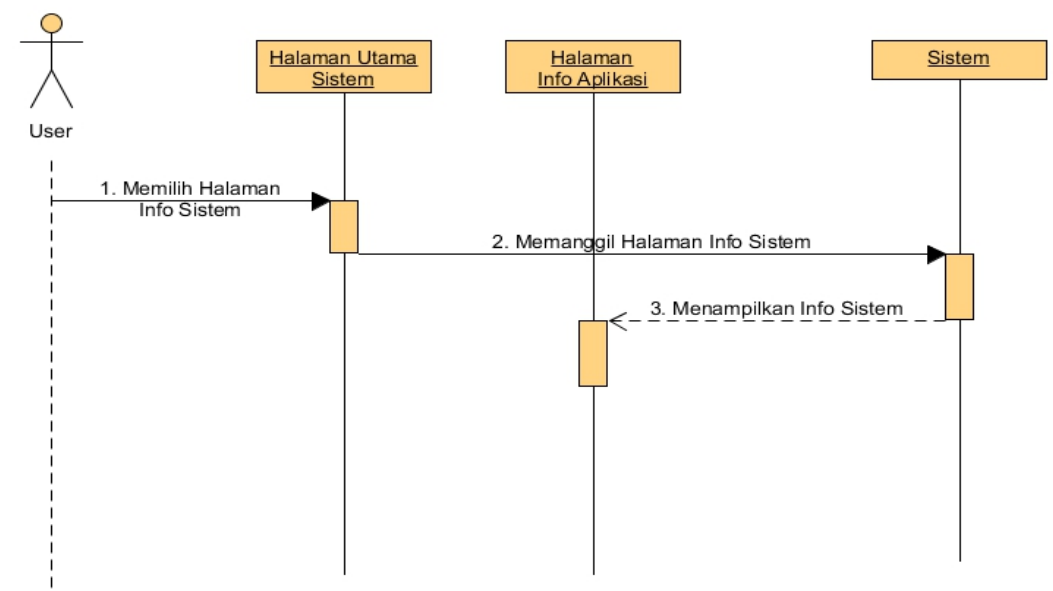

Gambar 9. Sequence Diagram Log In Firebase Console

\subsection{Hasil}

Pada aplikasi ini terdapat beberapa halaman yang dapat diakses oleh pengguna, diantaranya halaman awal, halaman studi, halaman materi ,halaman diskusi dan halaman quis. Adapun hasil implementasinya dapat dilihat sebagai berikut :

1. Halaman Beranda Studi

Pada halaman beranda studi berisikan materi-materi yang tersedia pada sistem media pembelajaran kreatif. Pengguna dapat mengakses bab pertama hingga bab ketiga, diskusi dan quis.

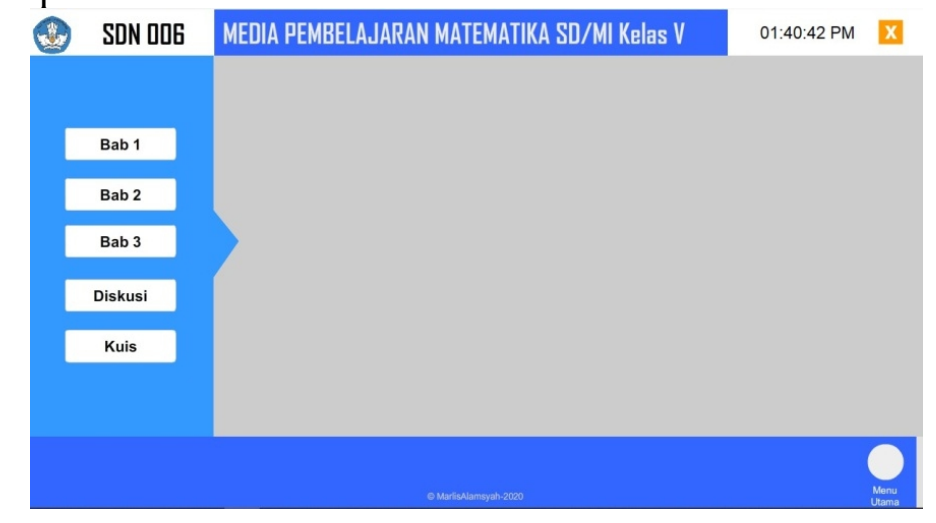

Gambar 10. Halaman Beranda Studi

2. Halaman Utama Materi Bab I

Halaman utama materi merupakan tampilan awal pada bab pertama studi matematika, pada halaman ini berisikan materi tentang bab pertama dan juga subbab-subbab lainnya yang dapat dipilih. 


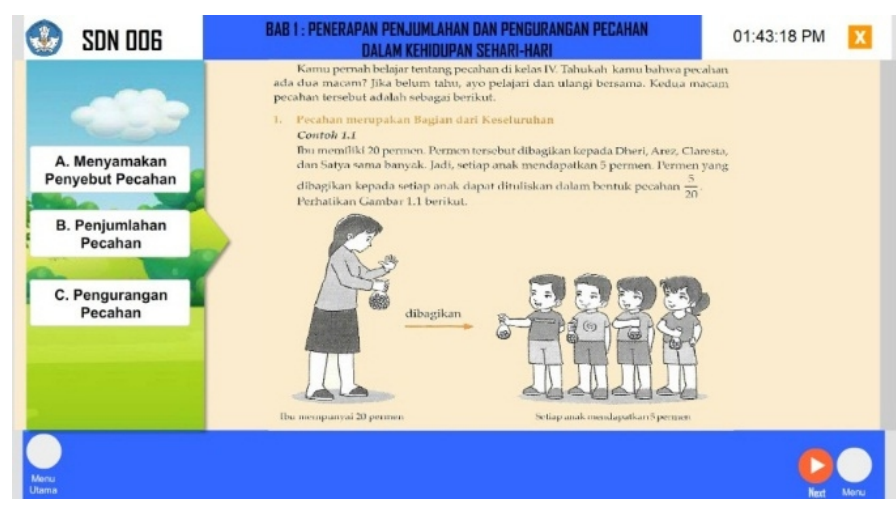

Gambar 11. Halaman Utama Materi Bab I

3. Halaman Subbab A Materi Bab I

Halaman subbab A materi Bab 1 merupakan bagian dari materi Bab I.

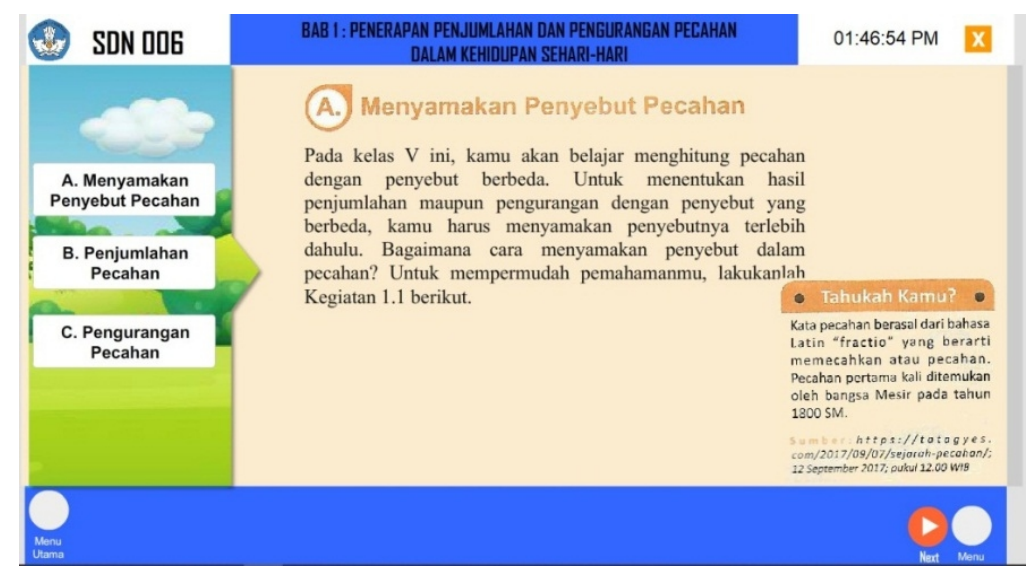

Gambar 12. Halaman Subbab A Materi Bab I

4. Halaman Diskusi A,B dan C

Halaman diskusi ini mencakup dari seluruh materi pada Bab 1.

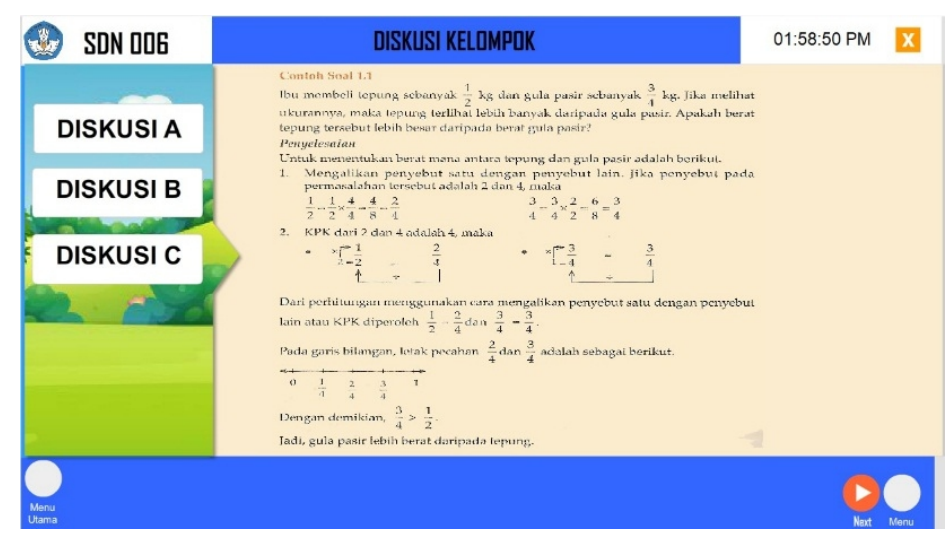

Gambar 13. Halaman Diskusi A 
Hal : $284-297$

5. Halaman Quis Uji Kompetensi I

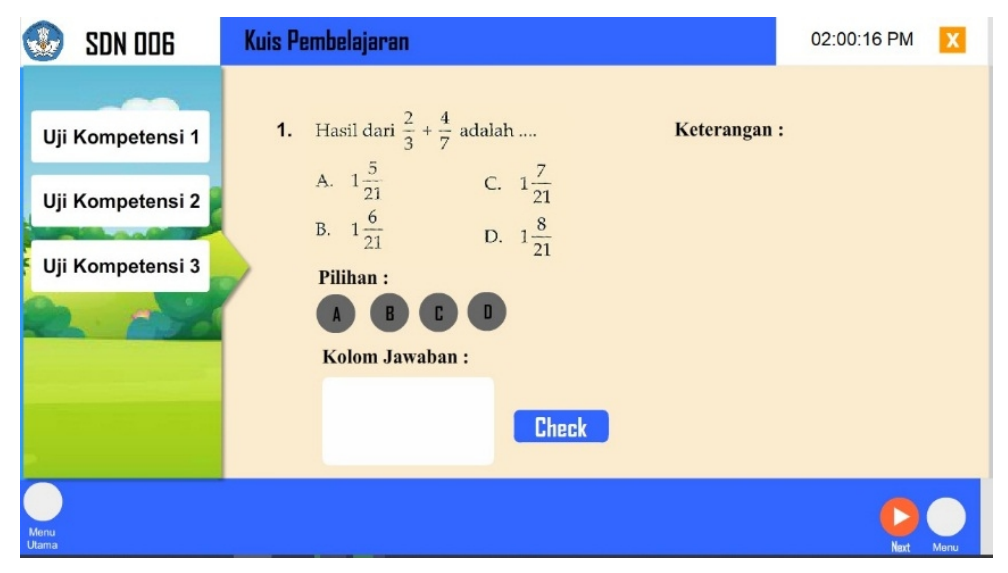

Gambar 14. Halaman Quis I

\subsection{Pengujian Sistem}

Pengujian sistem media pembelajaran meliputi tahapan yang harus dilakukan antara lain pengujian interface, pengujian ini dilakukan setelah sistem selesai dibangun.

\subsubsection{Pengujian Interface}

Pengujian interface ini bertujuan untuk memastikan fungsi-fungsi yang ada pada aplikasi sesuai dengan tahap perancangan yang telah ditetapkan sebelumnya, pengujian interface ini menggunakan teknik black box testing. Black box testing merupakan sebuah teknik pengujian yang menitik pusatkan kefungsional sistem yang telah siap dibangun.

Tabel 1. Pengujian Interface

Kelas Uji Skenario Pengujian Hasil Yang Diharapkan Hasil

\begin{tabular}{llll}
\hline $\begin{array}{l}\text { Pemilihan } \\
\text { Studi }\end{array}$ & $\begin{array}{l}\text { Memilih Studi } \\
\text { Matematika }\end{array}$ & $\begin{array}{l}\text { Sistem Menampilkan Studi } \\
\text { Matematika }\end{array}$ & Valid \\
\hline \multirow{2}{*}{$\begin{array}{l}\text { Pemilihan } \\
\text { Materi }\end{array}$} & Memilih Materi Bab I & $\begin{array}{l}\text { Sistem Menampilkan Materi } \\
\text { Bab I }\end{array}$ & Valid \\
\cline { 2 - 4 } & Memilih Materi Bab II & $\begin{array}{l}\text { Sistem Menampilkan Materi } \\
\text { Bab II }\end{array}$ & Valid \\
\cline { 2 - 4 } & Memilih Materi Bab III & $\begin{array}{l}\text { Sistem Menampilkan Materi } \\
\text { Bab III }\end{array}$ & Valid \\
& Memilih Materi & Sistem Menampilkan Materi & Valid \\
Pemilihan & Diskusi A & Diskusi A & \\
\cline { 2 - 4 } Diskusi & Memilih Materi & Sistem Menampilkan Materi & Valid \\
& Diskusi B & Diskusi A & \\
\cline { 2 - 4 } & Memilih Materi & Sistem Menampilkan Materi & Valid \\
& Diskusi C & Diskusi A & \\
\hline
\end{tabular}


$\mathrm{Hal}: 284-297$

\begin{tabular}{llll}
\hline \multirow{2}{*}{$\begin{array}{l}\text { Pemilihan } \\
\text { Quis }\end{array}$} & $\begin{array}{l}\text { Memilih Soal Uji } \\
\text { Kompetensi I }\end{array}$ & $\begin{array}{l}\text { Sistem Menampilkan Soal } \\
\text { Uji Kompetensi I }\end{array}$ & Valid \\
\cline { 2 - 4 } & $\begin{array}{l}\text { Memilih Soal Uji } \\
\text { Kompetensi II }\end{array}$ & $\begin{array}{l}\text { Sistem Menampilkan Soal } \\
\text { Uji Kompetensi II }\end{array}$ & Valid \\
\cline { 2 - 4 } & $\begin{array}{l}\text { Memilih Soal Uji } \\
\text { Kompetensi III }\end{array}$ & $\begin{array}{l}\text { Sistem Menampilkan Soal } \\
\text { Uji Kompetensi III }\end{array}$ & Valid \\
\end{tabular}

\subsubsection{Kesimpulan Hasil Pengujian}

Berdasarkan hasil pengujian pada sistem media pembelajaran kreatif menggunakan teknik pengujian black box testing, dapat diambil kesimpulan bahwa sistem media pembelajaran kreatif berfungsi dengan yang diharapkan.

\section{KESIMPULAN}

Dari hasil perancangan dan pengujian sistem yang telah dilaksanakan, maka dapat ditarik kesimpulan sebagai berikut:

1. Sistem media pembelajaran dapat menampilkan materi beserta contoh soal yang sesuai dengan kurikulum yang digunakan

2. Sistem juga dapat menampilkan video sebagai penarik minat siswa dalam memerhatikan materi dalam proses pembelajaran.

3. Berdasarkan penggunaan metode STAD dalam proses pembelajaran menggunakan media pembelajaran kreatif dapat menarik perhatian siswa dalam proses belajar mengajar.

4. Dengan adanya tahap diskusi dan kuis membuat para siswa lebih aktif dalam berinteraksi satu dengan lainnya.

\section{UCAPAN TERIMAKASIH}

Dengan berakhirnya penelitian yang dilakukan oleh penulis, bahwa hasil penelitian ini tidak akan terlaksana tanpa adanya pihak pihak yang memberikan dukungan. Penulis ingin menyampaikan terimakasih yang sebesar besarnya kepada Pihak Sekolah Dasar 006 Sungai Tonang Kampar Riau.

\section{DAFTAR PUSTAKA}

[1] Esminarto, et al. (2016).Implementasi Model STAD Dalam Meningkatkan Hasil Belajar Siswa. Briliant Journal: Journal Research and Conseptual. Vol.1,No.1,7-25.

[2] Hendini, A. (2016). Pemodelan UML Sistem Informasi Monitoring Penjualan Dan Stok Barang (Studi Kasus: Distro Zhezha Pontianak, Pontianak, Jurnal Khatulistiwa Informatika, Vol.IV,No.2.

[3] Ir. Yuni Sugiarti, M. K. (2013). Analisis \& Perancangan UML (Unified Modeling Language) Generated VB.6. Graha Ilmu, 30-45.

[4] Kalidah, M. (2015). Model Pembelajaran Kreatif Dalam Meningkatkan Minat Membaca Anak Diluar Sekolah. Jurnal UIN Sunan Kalijaga, Yogyakarta. Vol.12 No.1.

[5] Kurniati, A. (2015). Mengenalkan Matematika Terintegrasi Islam Kepada Anak Sejak Dini. Suska Journal of Mathematics Education Vol.1, No.1.

[6] Haroan Siregar (2016). Penerapan Model Pembelajaran Kooperatif Tipe Stad Untuk 
Meningkatkan Aktivitas dan Hasil Belajar Siswa Kelas X -1 SMA Negeri 1 Tanjung Pura Pada Pelajaran Kimia. Jurnal Penelitian Tindakan Kelas ISSN : 2301-6779

[7] Ida Wati.(2016). Peningkatan Kerjasama Pada Materi Perubahan Benda Menggunakan Model Pembelajaran Cooperative dengan Model STAD. Jurnal Penelitian Pendidikan Indonesia Vol.1,No.1.

[8] Muhammad Istiqlal.(2017).Pengembangan Multimedia Interaktif Dalam Pembelajaran Matematika. urnal Ilmiah Pendidikan Matematika Volume 2 Nomor 1.

[9] Salmon, S.F. et al. (2017). Penggunaan Metode Pose to Pose Dalam Pembuuatan Animasi 3D Tarian Manihasa Maengket. E-Journal Informatika, Volume 12, No.1(1), $1-6$

[10] Eddy Noviana.(2018) Penerapan Model Pembelajaran Kooperatif Tipe Stad Untuk Meningkatkan Hasil Belajar Pkn Siswa Kelas Iv Sd Negeri 79 Pekanbaru. Jurnal Pendidikan Guru Sekolah Dasar Fakultas Keguruan dan Ilmu Pendidikan Universitas Riau.

[11] Tofanao, T. (2018). Peranan Media Pembelajaran Dalam Meningkatkan Minat Belajar Mahasiswa. STT Kadesi, Yogyakarta. Jurnal Komunikasi Pendidikan, Vol.2,No.2. 